\title{
Impacts of climate change on runoff in the source area of the Yellow River
}

\author{
Dongying $\mathrm{Yi}^{1}$, Yue $\mathrm{Xu}^{1}$, Nan Wang ${ }^{1}$, and Xiaoyi $\mathrm{Ma}^{1}$ \\ ${ }^{1}$ Northwest A\&F University
}

July 27, 2021

\begin{abstract}
The primary approach to realizing long-term runoff prediction involves combining a hydrological model with general circulation model. Previous studies on the Source area of the Yellow River were all based on the Coupled Model Intercomparison Project Phase 5 (CMIP5) data sets with defects in physical mechanisms. In this paper, the Beijing Climate Center Climate System Model (BCC-CSM2-MR) of CMIP6, which proved to perform well in arid and semi-arid regions, will be used to drive the Soil \& Water Assessment Tool (SWAT) model and evaluate its applicability in runoff simulation at Tang Nahai Hydrological Station from 2011 to 2019. The occurrence of the extreme value of runoff, its change trend, and the year of abrupt change of runoff in the four Shared Socio-economic Pathway (SSP) scenarios (SSP1-2.6, 2-4.5, 3-7.0, and 5-8.5) during 2021-2100 were analyzed. The results show that: (1) the runoff simulation evaluation index of SWAT driven by BCC-CSM2-MR in the research area from 2011 to 2019 is excellent, and the runoff simulation in the future is reliable and effective. (2) only the average annual runoff in scenario 5-8.5 (708.5m / s) from 2021 to 2100 was significantly higher than that in 2011-2019. Other scenarios are close to or less than the annual runoff observed. Most importantly, the maximum and minimum annual runoff values under the four scenarios all occurred during 2060-2080, so the attribution analysis of runoff extremum during 2060-2080 is worth further study. (3) it is necessary to evaluate whether the existing reservoirs and hydropower stations in the Yellow River basin can reasonably regulate and utilize the annual runoff under scenario 5-8.5.
\end{abstract}

\section{Hosted file}

Impacts of climate change on runoff in the source area of the Yellow River.docx available at https://authorea.com/users/427727/articles/531855-impacts-of-climate-change-on-runoffin-the-source-area-of-the-yellow-river

\section{Hosted file}

Figure.pdf available at https://authorea.com/users/427727/articles/531855-impacts-ofclimate-change-on-runoff-in-the-source-area-of-the-yellow-river

\section{Hosted file}

Table.docx available at https://authorea.com/users/427727/articles/531855-impacts-ofclimate-change-on-runoff-in-the-source-area-of-the-yellow-river 